\title{
How autonomous should schools be? Research based on teacher opinions ${ }^{1}$
}

\author{
Süleyman Göksoy²
}

\begin{abstract}
The study intended to contribute to the quality of schools and teachers with the help of suggestions obtained from data and to shed light on regulations in school autonomy. Qualitative research method, which was thought to be more convenient to examine cases in depth, was used in this study and phenomenology was adopted. In order to provide maximum diversity, twenty four voluntary teachers were chosen from pre-school (5 teachers), primary school (7 teachers), secondary school (7 teachers) and high school (5 teachers). Following results were obtained related to more effective school management: Decisions related to teacher dismissal and dismissal of other staff should be taken by upper educational managers and not by schools; schools should be given full autonomy in making decisions about duties and responsibilities of school managers, giving overtime to teachers and other staff, paying for additional courses, choosing school managers, appointing substitutes for absent teachers and other staff and deciding the duties and responsibilities of teachers and other staff. Before schools and teachers are provided with more autonomy, effective, sufficient and qualified school managers should be selected, trained and assigned. Financial issues should be audited externally and controlled carefully.
\end{abstract}

Keywords: School, management, autonomy, school teacher

\section{1- Introduction}

Autonomy is a management style generated to eliminate or decrease the inconveniences of central management and bureaucratic mechanisms (Keleş, 1993; Tortop, 1991) and it requires self management (Püsküllüoğlu, 2002), independence in decision making and acting (Saran, 2004) and ability to take decisions and implement them with other parties at the school (Yüksel, 2005).

Autonomy aims to allow public organizations and institutions freedom to arrange their duties based on initiatives taken by themselves (Kalabalık, 1999). Therefore, the basic assumption in autonomy is that the management given autonomy will make efficient decisions and provide more suitable services for national interests (Yüksel, 2005). In this respect, autonomy given to institutions with the right to make decisions and implement these decisions is known as administrative autonomy (Keleş, 1993). Simply having the right to have freely formed or chosen instruments to make

\footnotetext{
${ }^{1}$ This study was oral presentation at $1^{\text {st }}$ International Conference On Lifelong Learning And Leadership For All (ICLEL). October 29th-31st, 2015, Palacky University \& Moravian University College Olomouc Olomouc, Czech Republic.

${ }^{2}$ Assist. Prof. Dr., Düzce University, Faculty of Education, Department of Educational Science, goksoys@hotmail.com (+90)5056885093 Düzce/Turkey
} 
Göksoy, S. (2016). How autonomous should schools be? Research based on teacher opinions. International Journal of Human Sciences, 13(1), 582-591. doi:10.14687/ijhs.v13i1.3553

decisions is not sufficient to be truly autonomous. Institutions must also have financial autonomy, in other words, the authority to spend resources without the influence of a central management in order to be called financially autonomous (Keleş, 1993; Tortop, 1991).

The European Union Council presents the boundaries of the concept of school autonomy, resources and human resources of school management, the dimensions of the learning-teaching process and 'school autonomy' in the European Union. Autonomy of schools can differ in varying dimensions (Eurydice, 2007,7). As a result of the growing autonomy of schools and of a decentralized management in the larger sense in the majority of European countries, teachers are given new responsibilities. It can be observed that as schools become more autonomous and more open as learning spaces, teachers become responsible for the content, arrangement and monitoring of the learning process as well as development of their own long-term career. In many countries these expectations are accompanied by an increase in the autonomy of teachers which allows them to carry out their duties. This type of autonomy is in tandem with a growing level of responsibility that doesn't depend only on teachers' capability to adhere to the operational procedures of the institution or evaluations of the results of these procedures. Within the concept of school autonomy, schools can be autonomous on different levels. In the case that a school is fully responsible from legal limitations and educational laws, it can be said that a school is fully or highly autonomous (Eurydice, 2008). School autonomy can be examined under several categories according to level of autonomy moving between full autonomy and no autonomy.

1- Full autonomy; The school can make all decisions within national legal limits without outside intervention. The school makes all decisions adhering to a pre-decided general draft pertaining only to education. The school makes all decisions after a cooperation with local, regional and central authorities. Suggestions and ideas may be supplied by authorities but the school is not dependent on these suggestions or ideas

2- Limited autonomy; The school makes decisions without the interference of a higher authority or an authority, however they must present these decisions to an authority and this authority can demand changes to the presented decisions The school makes decisions based on choices provided by a higher authority and is free to make other decisions if they are apporiate for the school.

3- No autonomy: The school can not make any decisions about their operations, the decisions are made only by educational authorities who consult the school

4- Optional authority: Local authorities can relay the power to make decisions to the school. This situation changes from one local management to the other (Eurydice, 2007,15).

Turkish educational system and ministry of education has a centralized structure. Many studies about centralized management underline the fact that these management style creates problems such as more paperwork, delayed tasks, inability to form relationships between school, family and community, inability to meet emergency needs, inability to make timely and correct investments, limiting the creativity of employees, employees turning out to be individuals who simply carry out orders, inability to raise educational standards, disowning problems that arise and incompetence in creating suggestions for solution (Bozan, 2002; Duman, 1998; Erdoğan, 2002; Eryllmaz, 1995; Gözübüyük, 1990; Köksal, 1999; Özgür, 2005; Özdemir, 1996; Şahin, 2003; Yavuz, 2001;). In examining the current situation, it can be said that increased school autonomy of the last twenty years in the European Union is the cause of increasing responsibilities of teachers (Eurydice, 2008,12). 


\section{2- Research Aims}

Current study aimed to present the views of teachers in Turkey pertaining to how autonomous schools should be. The study intended to ameliorate the quality of schools and teachers as well as shed light for future restructuring of schools via suggestions based on study data. The study sought answers to the following questions;

What are the opinions of teachers about "management of human resources" in the field of school autonomy?

What are the opinions of teachers about "management of financial resources" in the field of school autonomy?

What are the opinions of teachers about "management of learning-teaching process" in the field of school autonomy?

\section{3- Method}

Qualitative research method was used in this research. Qualitative research method was thought to be more suitable for this study since it allows examining the cases in depth. Phenomenology was adopted in this research since phenomenological pattern has been considered the center of the qualitative study understanding (Mayring, 2000). Phenomenological pattern focuses on phenomena of which we are aware but lack deep and detailed understanding (Yıldırım and Şimşek, 2008).

Validity and Reliability of the Study; Construct validity: throughout the study, data based on semi-structured interview forms were presented without subjective judgments of the researcher. Internal validity: In order to ensure internal validity, the researcher attempted to present how the results were obtained in a clear and open manner and presented the data in a manner accessible for others. External validity: External validity is related to the generalization of results and generalization in the current study (analytical generalization) will be related to the level of autonym required at schools. Reliability: Reliability is related to receiving the same or similar results when the study is replicated by other researchers. In order to ensure reliability, the researcher in the current study defines the processes, supports the definition with the help of related documents, presents the results in a system and preserves the data base and records of the data to be used by other researchers when necessary.

\section{Study Group}

Purposive sampling method, maximum diversity and criterion sampling were used while selecting the study group. Purposive sampling method allows studying abstruse cases in depth (Büyüköztürk et. al, 2012; Yıldırım and Şimşek, 2008). Criteria for participation was based on having permanent teaching posts (and having completed candidacy procedures) and having worked for at least three years by the time of the study. These criteria were selected since it was believed that active and experienced teachers would have higher awareness regarding the topic of the study. In order to provide maximum diversity, twenty four voluntary teachers were chosen from pre-school (5 teachers), primary school (7 teachers), secondary school (7 teachers) and high school (5 teachers). Information about the participants is given in Table 1. 
Göksoy, S. (2016). How autonomous should schools be? Research based on teacher opinions. International Journal of Human Sciences, 13(1), 582-591. doi:10.14687/ijhs.v13i1.3553

Table 1.

\begin{tabular}{|c|c|c|c|}
\hline Variables & Sub Categories & f & $\%$ \\
\hline \multirow{2}{*}{ Gender } & Female & 12 & 50 \\
\hline & Male & 12 & 50 \\
\hline \multirow{3}{*}{$\begin{array}{l}\text { Level } \\
\text { education }\end{array}$} & Two year degree & - & - \\
\hline & $\begin{array}{l}\text { Four year degree } \\
\text { Masters }\end{array}$ & 24 & 100 \\
\hline & Doctorate & - & - \\
\hline \multirow{5}{*}{ Years of service } & $1-5$ years & 5 & 21 \\
\hline & $6-10$ years & 10 & 41 \\
\hline & $11-15$ years & 5 & 21 \\
\hline & $16-20$ years & 4 & 17 \\
\hline & $\begin{array}{c}25 \text { years and } \\
\text { higher }\end{array}$ & - & - \\
\hline
\end{tabular}

Table 1 shows that all teachers who participated in the study were graduates of four year programs. While $21 \%$ of teachers had 1-5 or 11-15 years of service, the majority, $41 \%$ of participants had 6-10 years of professional experience.

\section{Data Collection Tool}

The study employed a semi-structured interview form as the data collection tool. The form was designed and developed by the researcher based on the basic fields and sub categories in schools (1. Human resources, 2. Fiscal/ financial resources, 3. Learning-teaching process) as defined in the study To what extent should schools be autonomous? (Göksoy, 2014). Semi-structured interviews allow participants to express themselves (Büyüköztürk et al., 2012). Teachers and academicians were consulted in the process of form development and the form was finalized based on the ideas and suggestions gathered from these consultations. Participants were asked the following questions:

What are the opinions of teachers about "management of human resources" in the field of school autonomy?

What are the opinions of teachers about "management of financial resources" in the field of school autonomy?

What are the opinions of teachers about "management of learning-teaching process" in the field of school autonomy?

\section{Data Analysis}

Descriptive analysis was used in the study as a qualitative data analysis technique. Teacher responses to questions during interviews were recorded in writing. Teachers were interviewed face to face for about an hour and a half for the purposes of the study and the responses were written down instantly. The written notes were read back to participants at the end of the study for approval. To ensure privacy, participants were specified with an abbreviations and numbers such as Teacher (T1) and every participant was assigned a number. Data were grouped according to themes and content analysis was carried out. The themes were identified based on related literature, codes were generated, content analysis was carried out and the findings were presented.

\section{4-Results}

This section presents the views of teachers participating in the study. Findings and comments related to subcategories of the study are presented below. 
Göksoy, S. (2016). How autonomous should schools be? Research based on teacher opinions. International Journal of Human Sciences, 13(1), 582-591. doi:10.14687/ijhs.v13i1.3553

\section{$A$ - Regarding “Autonomy of Human Resources Management”}

The views of teachers pertaining to school autonomy in terms of human resources management are provided in Table 2.

\section{Table 2}

Autonomy of Human Resources Management

\begin{tabular}{|c|c|c|c|c|}
\hline $\begin{array}{l}\text { Main } \\
\text { Theme }\end{array}$ & $\begin{array}{c}\text { Level of } \\
\text { Autonomy }\end{array}$ & Sub Category & Justification/ Sample Sentences & f \\
\hline \multirow{5}{*}{$\begin{array}{l}\text { Human } \\
\text { Resources }\end{array}$} & \multirow{5}{*}{$\begin{array}{l}\text { Full } \\
\text { Autonomy }\end{array}$} & $\begin{array}{l}\text { Decisions about the duties } \\
\text { and responsibilities of } \\
\text { school administrators }\end{array}$ & $\begin{array}{l}\text { Only people who work within the structure of a } \\
\text { school can know the needs of a school and how to } \\
\text { meet these needs (T3), creates participative } \\
\text { management (T5). }\end{array}$ & 19 \\
\hline & & $\begin{array}{l}\text { Payment for overtime for } \\
\text { teachers and other } \\
\text { employees }\end{array}$ & $\begin{array}{l}\text { It is necessary to work outside of usual work hours } \\
\text { to complete the workload in time (T1), teachers } \\
\text { having higher levels of motivation will reflect on } \\
\text { quality (T6) }\end{array}$ & 15 \\
\hline & & $\begin{array}{l}\text { Selection of school } \\
\text { administrators }\end{array}$ & $\begin{array}{l}\text { Every school has a distinct structure (T2), School } \\
\text { employees want to see people they are happy working } \\
\text { with as administrators (T5) With the condition } \\
\text { that merit is taken into consideration in } \\
\text { administrators (T20) }\end{array}$ & 13 \\
\hline & & $\begin{array}{l}\text { Reassigning teachers and } \\
\text { other employees who } \\
\text { don't come to work }\end{array}$ & $\begin{array}{l}\text { Ensures work and operation completion in shorter } \\
\text { time periods. Prevents loss of efficiency (T1) }\end{array}$ & 13 \\
\hline & & $\begin{array}{l}\text { Decisions about duties and } \\
\text { responsibilities of teachers } \\
\text { and other employees }\end{array}$ & $\begin{array}{l}\text { Will raise quality of personnel and education (T4), } \\
\text { operation will become clearer and more easily } \\
\text { controllable (T7), however with the condition that } \\
\text { administrators (T10) }\end{array}$ & 12 \\
\hline $\begin{array}{l}\text { Human } \\
\text { Resources }\end{array}$ & $\begin{array}{l}\text { No } \\
\text { Autonomy }\end{array}$ & $\begin{array}{l}\text { Dismissal of teachers and } \\
\text { other employees }\end{array}$ & $\begin{array}{l}\text { The effects of political views may give way to unfair } \\
\text { implementations (T2), there will be an increase in } \\
\text { string pulling (T12), an environment where } \\
\text { administrators reward people with whom they are } \\
\text { aligned and punish others may be created, quality } \\
\text { may decrease (T15) Decisions may not be related to } \\
\text { data (T3), }\end{array}$ & 21 \\
\hline
\end{tabular}

Participants in the study group felt that no autonomy should be given to schools in the subcategory of "Dismissal of teachers and other employees" because of a fear that principles of objectivity, rights and justice would be vulnerable. In other words, they felt that decisions about "Dismissal of teachers and other employees" should be made by higher educational authorities rather than within the school structure $(\mathrm{n}=21)$. The teachers expressed that they wanted schools to be given full autonomy in the other dimensions of the human resources subcategory and a belief that this would make school function more effectively and efficiently.

\section{$B$ - Regarding “Autonomy of Fiscal/Financial Resources Management"}

Teacher views pertaining to school autonomy related to fiscal/financial resources management are provided in Table 3. 
Göksoy, S. (2016). How autonomous should schools be? Research based on teacher opinions. International Journal of Human Sciences, 13(1), 582-591. doi:10.14687/ijhs.v13i1.3553

\section{Table 3}

Autonomy of Fiscal/Financial Resources Management

\begin{tabular}{|c|c|c|c|c|}
\hline $\begin{array}{c}\text { Main } \\
\text { Theme }\end{array}$ & $\begin{array}{c}\text { Level of } \\
\text { Autonomy }\end{array}$ & Subcategories & Justification/Sample Sentences & f \\
\hline \multirow{6}{*}{$\begin{array}{l}\text { Fiscall } \\
\text { Financial } \\
\text { Resources }\end{array}$} & \multirow{6}{*}{$\begin{array}{l}\text { Full } \\
\text { Autonomy }\end{array}$} & $\begin{array}{l}\text { Earning or } \\
\text { spending money, } \\
\text { managing money }\end{array}$ & $\begin{array}{l}\text { Schools are driven to belplessness by the system because the } \\
\text { government doesn't provide sufficient support to schools. The } \\
\text { autonomy provided will both pave the way for schools and } \\
\text { ensure the implementation of new projects (T17). I believe } \\
\text { that funds aren't justly allocated to schools in our country. } \\
\text { While some schools have all the opportunities they need for } \\
\text { educational purposes, others can't even afford their most basic } \\
\text { needs. Problems such as these can at least be partially solved. } \\
\text { Each school can have the right to create and more effectively } \\
\text { spend their own resources (T19). I think that schools should be } \\
\text { run by the parent teacher associations and that this will } \\
\text { diminish the amount of paperwork (T20). [Fiscal/financial } \\
\text { resources] should be autonomous, however they should be used } \\
\text { by an entity outside of the administration, formed in the school } \\
\text { (T22). }\end{array}$ & 16 \\
\hline & & $\begin{array}{l}\text { Finding funds } \\
\text { from donators } \\
\text { and sponsors }\end{array}$ & $\begin{array}{l}\text { Central management does not sufficiently meet the constantly } \\
\text { increasing needs of schools (T6). Including families in learning- } \\
\text { teaching expenditures, using sponsorships or renting out } \\
\text { physical resources are systems that can provide financial } \\
\text { improvement for schools. However it would be bealthier for } \\
\text { fiscal controls to be regularly carried out by the government at } \\
\text { this stage (T8). Donations are beld up by legal procedures and } \\
\text { schools should be able to directly accept donations from donors } \\
\text { (T13). }\end{array}$ & 13 \\
\hline & & $\begin{array}{l}\text { Selecting } \\
\text { administrators; } \\
\text { renting out } \\
\text { physical } \\
\text { resources of } \\
\text { schools outside } \\
\text { educational hours }\end{array}$ & $\begin{array}{l}\text { Schools should be able to use and rent out their own grounds } \\
\text { after learning-teaching is over for the day. By doing this } \\
\text { principals can show their management roles in cooperation with } \\
\text { their community (T12). Schools will be able to use the money } \\
\text { they gain this way to ameliorate educational activities and } \\
\text { quality will increase (T15). It may be feasible with the } \\
\text { condition of a very tight supervision mechanism (T16). }\end{array}$ & 13 \\
\hline & & $\begin{array}{l}\text { Using the } \\
\text { unmovable } \\
\text { property income } \\
\text { of the school }\end{array}$ & $\begin{array}{l}\text { An administrator should not only be the person who tries to } \\
\text { run the school with the money be or she receives from the } \\
\text { government, but also the person who tries to use the incomes of } \\
\text { the properties of the school in the best way (T10). Schools } \\
\text { aren't allocated large enough budgets by central management } \\
\text { and they suffer financial hardship because of this. School yards } \\
\text { can be rented out as parking lots outside of learning-teaching } \\
\text { hours or gyms can be rented to the public or to private } \\
\text { institutions (T11). }\end{array}$ & 9 \\
\hline & & $\begin{array}{l}\text { Appointing } \\
\text { educators and } \\
\text { non educators } \\
\text { using private } \\
\text { school funds }\end{array}$ & $\begin{array}{l}\text { One of the biggest problems schools face today is the problem of } \\
\text { insufficient personnel. The quality of the learning-teaching } \\
\text { process will increase with allocated budgets (T17). May be } \\
\text { feasible with the appointment of quality school administrators } \\
\text { (T18). The effects will be positive. Schools will create their own } \\
\text { funds and will be able to ameliorate their existing resources } \\
\text { thanks to these funds (T22) }\end{array}$ & 8 \\
\hline & & $\begin{array}{l}\text { Using the movable } \\
\text { property income of } \\
\text { the school }\end{array}$ & $\begin{array}{l}\text { Fiscal autonomy is necessary to get past bureaucratic burdles. } \\
\text { One way of creating fiscal resources is for schools to bave } \\
\text { movable property incomes and to use this income in a way that } \\
\text { is appropriate for school goals. Centralized management will } \\
\text { both slow things down and render them inefficient. Central } \\
\text { managements also don't have a good knowledge of the schools } \\
\text { and the resources they have (T17). }\end{array}$ & 8 \\
\hline
\end{tabular}


Göksoy, S. (2016). How autonomous should schools be? Research based on teacher opinions. International Journal of Human Sciences, 13(1), 582-591. doi:10.14687/ijhs.v13i1.3553

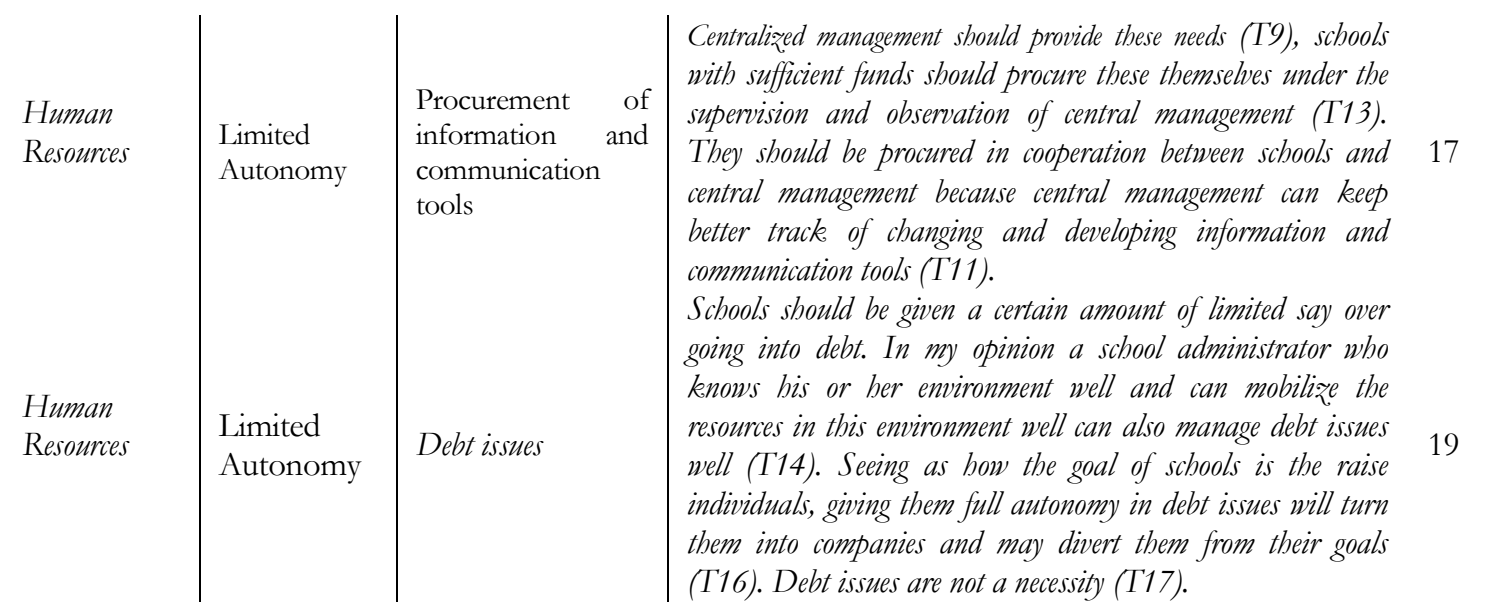

The teachers who participated in the study were generally of the view that full autonomy should be given to schools in respect of fiscal/financial resources management but the following conditions should be taken into consideration:

a) Before schools and teachers are provided with more autonym, effective, sufficient and qualified school managers should be selected, trained and assigned.

b) Financial issues should be audited externally and controlled carefully.

c) Schools should not be transformed into companies.

d) If possible, financial issues should be maintained outside of the school by independent units such as parent-teacher associations.

e) Since continuous pursuit of innovations, advancement and development is important, schools and central management should work together to provide information and communication technologies to the whole school.

f) Since it may carry some risks, schools should be given limited autonomy in debt issues.

\section{$C$ - Regarding "Autonomy of the Learning-Teaching Process"}

Teacher views pertaining to school autonomy related to Autonomy of the Learning-Teaching Process are provided in Table 4.

\section{Table 4}

\section{Autonomy of the Learning-Teaching Process}

\begin{tabular}{|c|c|c|c|c|}
\hline $\begin{array}{c}\text { Main } \\
\text { Theme }\end{array}$ & $\begin{array}{c}\text { Level of } \\
\text { Autonomy }\end{array}$ & Subcategory & Justification/Sample Sentences & f \\
\hline \multirow{2}{*}{$\begin{array}{l}\text { Learning- } \\
\text { Teaching } \\
\text { Process }\end{array}$} & \multirow[t]{2}{*}{$\begin{array}{l}\text { Full } \\
\text { Autonomy }\end{array}$} & $\begin{array}{l}\text { Deciding whether } \\
\text { students pass or } \\
\text { fail a class }\end{array}$ & $\begin{array}{l}\text { It should be done by several teams, not left to the authority and } \\
\text { responsibility of only the principal (T3). Schools should be } \\
\text { given the right to decide in this respect especially. In the current } \\
\text { system it's almost impossible to fail even the students who don't } \\
\text { show up for class or take their exams (T4). This is the field in } \\
\text { which I most want autonomy. In the current system there is } \\
\text { practically no failing. Students pass the class even if they are } \\
\text { absentee or unsuccessful (T8). }\end{array}$ & $\begin{array}{l}2 \\
2\end{array}$ \\
\hline & & $\begin{array}{l}\text { Selecting optional } \\
\text { courses and their } \\
\text { programs }\end{array}$ & $\begin{array}{l}\text { I believe that the best decisions in this process wil be made by } \\
\text { us, the implementers (T2). If teachers are given say during the } \\
\text { process of preparing programs and classes, they will try to be } \\
\text { more active in the implementation (T8). Every place needs } \\
\text { different compulsory and optional courses. For example it } \\
\text { might not be strictly necessary to provide a course on water }\end{array}$ & 14 \\
\hline
\end{tabular}


Göksoy, S. (2016). How autonomous should schools be? Research based on teacher opinions. International Journal of Human Sciences, 13(1), 582-591. doi:10.14687/ijhs.v13i1.3553

\begin{tabular}{|c|c|c|c|c|}
\hline & & & \multicolumn{2}{|l|}{ products in a landlocked county (T3). } \\
\hline & & $\begin{array}{l}\text { Selecting teaching } \\
\text { methods }\end{array}$ & $\begin{array}{l}\text { Actually, we are currently pretty independent in this respect } \\
\text { and I believe it should continue like this (T3). However, all } \\
\text { activities should be open to internal and external inspection } \\
\text { (T5). Teaching methods should be selected proximal-distally } \\
\text { and according to student levels (T9). }\end{array}$ & 10 \\
\hline & & $\begin{array}{l}\text { Selecting text } \\
\text { books }\end{array}$ & $\begin{array}{l}\text { I'm on the side of autonomy in this respect. For example, the } \\
\text { currently used Science and Technology text books and activity } \\
\text { books which prepared by the central management have } \\
\text { practically no content (T1). }\end{array}$ & 9 \\
\hline & & $\begin{array}{l}\text { Defining } \\
\text { evaluation criteria } \\
\text { for students in } \\
\text { compulsory subject } \\
\text { activities }\end{array}$ & $\begin{array}{l}\text { These activities should be carried out by school management } \\
\text { boards and several teams formed in the school (T4). }\end{array}$ & 7 \\
\hline & & $\begin{array}{l}\text { Taking part in } \\
\text { preparation of } \\
\text { graduation exams } \\
\text { and documents }\end{array}$ & $\begin{array}{l}\text { I have no say at all in the current system, this way I'll at least } \\
\text { bave some say in the preparation of documents (T1). The } \\
\text { bureaucratic work load of central management would also } \\
\text { diminish (T7). }\end{array}$ & 7 \\
\hline & & $\begin{array}{lr}\text { Defining } & \text { criteria } \\
\text { for in } & \text { class } \\
\text { evaluation } & \text { of } \\
\text { students } & \end{array}$ & $\begin{array}{l}\text { A more fair system of evaluation for students would emerge } \\
\text { (T2). }\end{array}$ & 5 \\
\hline $\begin{array}{l}\text { Learning- } \\
\text { Teaching } \\
\text { Process }\end{array}$ & $\begin{array}{l}\text { Limited } \\
\text { Autonomy }\end{array}$ & $\begin{array}{l}\text { Selecting } \\
\text { compulsory classes } \\
\text { and programs }\end{array}$ & $\begin{array}{l}\text { Cooperation with central management is necessary because } \\
\text { preparation of teaching programs requires expertise (T4). } \\
\text { Schools can decide as long as they conform to the basic } \\
\text { principles and policies decided by the government (T9). Course } \\
\text { programs are more important than whether they are optional or } \\
\text { compulsroy. Schools should be more active in the preparation of } \\
\text { the programs (T4). Compulsory courses and their programs } \\
\text { should be prepared and implemented together by schools with } \\
\text { the control, supervision and guidance of central management. }\end{array}$ & 20 \\
\hline
\end{tabular}

Based on research data, teachers had the following views regarding school autonomy of the learning-teaching process

a) Since preparation and development of compulsory courses and teaching programs according to basic principles and policies of the government require proficiency, schools should be given limited autonomy in this area and schools should work together with central management.

b) All activities should be audited internally and externally and autonomy should be given only with the requirement to make internal and external audits.

c) Teaching-learning activities should be carried out by school management establishments and several other teams, provided that school manager is not alone deciding about those issues.

\section{5- Discussion - Conclusion}

The current study that aimed to portray how autonomous schools should be based on teacher views obtained the following findings related to effective and efficient school management:

A) About the autonomy of management of human resources: 
- "Decisions related to teacher dismissal and dismissal of other staff should be taken by upper educational managers and not by schools,

- Schools should be given full autonomy in making decisions about duties and responsibilities of school managers, giving overtime to teachers and other staff, paying for additional courses, selecting school managers, appointing substitutes for absent teachers and other staff and deciding the duties and responsibilities of teachers and other staff. Findings of the current research are parallel with those found in the study by Göksoy (2014) undertaken with school managers. In Göksoy's research, school managers also thought that authority to dismiss teachers and other staff should be given to upper management; otherwise it would cause controversies between school managers and the dismissed personnel.

B) About the autonomy of financial resources of schools:

a) Before schools and teachers are provided with more autonym, effective, sufficient and qualified school managers should be selected, trained and assigned.

b) Financial issues should be audited externally and controlled carefully.

c) Schools should not be transformed into companies.

d) If possible, financial issues should be maintained outside of the school by independent units such as parent-teacher associations.

e) Since continuous pursuit of innovations, advancement and development is important, schools and central management should work together to provide information and communication technologies to the whole school.

f) Since it may carry some risks, schools should be given limited autonomy in debt issues.

C) About the autonomy of teaching-learning process in schools,

a) Since preparation and development of compulsory courses and teaching programs according to basic principles and policies of the government require proficiency, schools should be given limited autonomy in this area and schools should work together with central management.

b) All activities should be audited internally and externally and autonomy should be given only with the requirement to make internal and external audits.

c) Teaching-learning activities should be carried out by school management establishments and several other teams, provided that school manager is not alone deciding about those issues.

While results obtained regarding the autonomy of financial resources and teaching-learning processes are partially parallel with the results of the research by Göksoy (2014) conducted with school managers, there are also some differences. Although school managers would like to be the only decision-makers in financial issues, teachers think that it is more efficient to make decisions with the help of organizations and commissions generated in schools. Unlike school managers, teachers think that schools should have limited rights in debt issues and in the provision of information-communication technologies. Also teachers suggest that increasing internal and external audit to be parallel with autonomy will increase quality in schools. So based on research data also can be this suggestions; About the autonomy of management of human resources in schools: Autonomy in schools should be increased except for the decision of dismissing teachers and other staff. Since continuous pursuit of innovations, advancement and development is important, schools and central management should work together to provide information and communication technologies. With the autonomy in teaching-learning activities, all activities should 
Göksoy, S. (2016). How autonomous should schools be? Research based on teacher opinions. International Journal of Human Sciences, 13(1), 582-591. doi:10.14687/ijhs.v13i1.3553

be continuously audited internally and externally. Teaching-learning activities should be carried out by school management establishments and several other teams provided that school manager is not alone deciding about those issues.

\section{References}

Bozan M 2002. Merkesiyetçi Yönetimden Yerinden Yönetime Geçişte Alternatif Yaklașımlar: Milli Eğitim Bakanlĭg Örmeği. Yayımlanmamış Doktora Tezi, Malatya: İnönü Üniversitesi.

Büyüköztürk Ş, Kilıç ÇE, Akgün ÖE, Karadeniz Ş, Demirel F 2012. Bilimsel Araştırma Yöntemleri (Geliștirilmiş 11. Basker). Ankara: Pegem A Akademi.

Duman A 1998. Eğitimin yerinden yönetimi. Çăgdas Yerel Yönetimler Dergisi. 2, 83-93.

Erdoğan I 2002. Yeni Bir Binynla Doğru Türk Eğitim Sistemi Sorunlar Ve Cö̈zümler. İstanbul: Sistem Yayincilik.

Eryllmaz B 1995. Kamu Yönetimi. İzmir: Akademi Kitabevi.

Eurydice 2001. Information and Communication Technology in European Education Systems (ICT@Europe.edu).Brussels: Eurydice.

Eurydice 2007. School Autonomy in Europe policies and Measures, Printed in Belgium.

Eurydice, 2004. Key Data on Information and Communication Technology in Schools in Europe. Edition.Brussels: Eurydice.

Eurydice 2008. Avrupa'da Okul Özerkliği: Politikalar ve Önlemler, Avrupa Komisyonu (Eğitim ve Kültür Genel Müdürlüğü) Mali Desteği ile Eurydice Avrupa Birimi tarafindan yayınlanmıştır. Belgeye http: http://www.eurydice adresinden ulaşılmıştır.

Göksoy S 2014. To what extent should schools be autonomous?, Educational Research and Reviews, 9(1), ss. 24-33, http://www.academicjournals.org/ERR, DOI:10.5897/ERR2013.1679 ISSN 1990-3839 Indexed by: ERIC, Academic Journals http://www.academicjournals.org/ERR.

Gözübüyük AŞ 1990. Kamu Yönetimi Hukuku. Ankara: "S" Yayınlar1.

Kalabalık H 1999. Yerel yönetimlerin idari özerkliği. Belediye Dergisi, 5 (11),

Keleş R 1993. Kent ve Siyaset Üzrerine Yažlar (1975-1992), İstanbul: IULA-EMME,

Köksal K 1999. Yerinden yönetime evet ancak. Kuram ve Uygulamada Eğitim Yönetimi Dergisi, (17), 119-124.

Özgür HN 2005. Ë̆itim Bölgeleri Ve Eğitim Kurullarnm Olușturulması Ve Calsştırlmasına Ilişkin Etkinliklerin Değerlendirilmesi (Hatay örneği). Yayımlanmamış Yüksek Lisans Tezi, Hatay: Mustafa Kemal Üniversitesi.

Püsküllüoğlu A 2002. Türkşe Söəlük, Doğan Kitap, Güncelleştirilmiş Dördüncü Bask1, İstanbul.

Saran MU 2004. Kamu Yönetiminde Yeniden Yapılanma. Ankara: Atlas Yayınları.

Şahin S 2003. Okul Merkezli Yönetim Uygulamaları. Kuram ve Uygulamada Eğitim Yönetimi Dergisi. 9(36), 582-605.

Tortop N 1991. Özerk, üreten ve katıllımcı mahalli idare anlayış1. Amme İdaresi Dergisi, Cilt 24, Say1 4 ,

Yavuz Y 2001. Lise Yöneticilerinin Ve Öğretmenlerinin Okulda Yerinden Yönetim Ve Merkęden Yönetim Yaklaşımlarna Ilişkin Görüslerinin Karar Verme Sürecine Etkileri. Yayınlanmamış Doktora Tezi İzmir: Dokuz Eylül Üniversitesi.

Yüksel F 2005. Yerel Özerklik Kavramı Üzerine Bir İnceleme, Hüseyin Özgür ve Muhammet Kösecik (Ed.): Yerel Yönetimler Üzerine Güncel Yažlar İçinde 13. Bölüm, Ankara: Nobel Yayın Dağitım,

Zencirci İ 2003. İlköğretim Okullarnda Yönetimin Demokratiklik Düzeyinin Katılım, Özgürlük Ve Özerklik Boyutlar Açısından Değerlendirilmesi: Balıkesir İli Örneği, Yayınlanmamış Doktora Tezi. Ankara: Ankara Üniversitesi 